\title{
Zagospodarowanie parcel mieszczańskich w Pucku jako źródło poznania przemian kulturowych w małym mieście lokacyjnym w późnym średniowieczu
}

\section{Organization of the burghers' plots in Puck as evidence of cultural changes in a small incorporated town in the Late Middle Ages}

Zarys treści. W artykule przedstawiono zagadnienie zagospodarowania parcel mieszczańskich w Pucku oraz poruszono problematykę przemian, jakim podlegała przestrzeń prywatna w małym mieście lokacyjnym w późnym średniowieczu.

Słowa kluczowe: Puck; miasto; parcela; zagospodarowanie; późne średniowiecze.

Problematyka przemian kulturowych u progu późnego średniowiecza na ziemiach polskich od wielu dziesięcioleci znajduje się w centrum zainteresowań badaczy różnych specjalności. Mimo niekwestionowanego i znacznego dorobku tych badań bez wątpienia nadal jest to temat niewyczerpany, skupiający uwagę historyków, archeologów, historyków architektury i wielu innych badaczy (np. Małowist 1973; Wędzki 1974; Zientara 1976; Historia 1978; Ihnatowicz, Mączak, Zientara 1979, s. 97-225; Kruppé 1981; Buśko 1998; Dzieduszycki 1998; Archeologia historyczna 2000; Rębkowski 2001). Swą popularność zawdzięcza przy tym zarówno ogromnej różnorodności podejmowanych zagadnień, jak i ciągłemu przyrostowi istotnych danych źródłowych, wymagających nowego spojrzenia na poszczególne wątki przeobrażeń społeczno-gospodarczych mających miejsce głównie w XIII wieku. Jak pokazują wyniki prac badawczych w niektórych regionach czas ten należałoby rozciągnąć także i na następne stulecie.

Jednym z obszernych zagadnień związanych z powyższą problematyką jest kształtowanie się ośrodków miejskich, wielokrotnie już poruszane w literaturze przedmiotu (m.in. Wyrobisz 1968; Lalik 1975; 1976; Zientara 1976; Bogucka, Samsonowicz 1986). Ważną i nierozerwalnie powiązaną z tą tematyka kwestią 
jest parcela mieszczańska: jej wymiary, zagospodarowanie i przemiany, jakim podlegała w późnym średniowieczu. Jako zjawisko również doczekała się ona wielu omówień (m.in. Münch 1946; Zagrodzki 1962; Lalik 1963; Pudełko 1964a; 1964b; Żaryn 1972; Kierzkowska-Kalinowska 1975; Berdecka 1982; Buśko 1995; Zarębska 1995; Gupieniec 1997; Młynarska-Kaletynowa 1997; 2006; Krasnowolski 2004; Wyrobisz 2010), jednak z reguły dotyczyło to miast dużych bądź średnich, w mniejszym stopniu zaś małych. Poza nielicznymi wyjątkami działkę lokacyjną badano przy pomocy metody planistycznej, ograniczając się do analizy układu urbanistycznego (Młynarska-Kaletynowa 1997, s. 17). Przyczyny takiej sytuacji wynikały zarówno z niewielkiej liczby zachowanych źródeł pisanych, jak i słabego zaawansowania badań wykopaliskowych prowadzonych na terenie działek. Podobną zależność odnotowano na Pomorzu Gdańskim, gdzie zainteresowaniem badawczym objęto wyłącznie stołeczny Gdańsk (Bobiński 1952; Polak 2007; 2009; Krzywdziński 2009), zaś dorobek badań nad późnośredniowieczną parcelą w innych miastach regionu jest - jak dotąd - niewielki (Betlejewska 2004). Bez wątpienia zatem istnieje luka dotycząca charakterystyki zagospodarowania i przemian kulturowych związanych z funkcjonowaniem działki mieszczańskiej w małym mieście na Pomorzu Gdańskim.

Zagadnienie to chciałem zaprezentować na przykładzie Pucka ${ }^{1}$, bazując na rezultatach wieloletnich badań archeologicznych prowadzonych na terenie tamtejszego miasta lokacyjnego (Blusiewicz, Kruppé, Milewska, Starski 2014). W przypadku Pomorza Gdańskiego w żadnym innym ośrodku tej rangi nie uzyskano jednocześnie na tyle licznych danych, aby podejmować podobną próbę ${ }^{2}$. Na podstawie wyników prac badawczych, a także zachowanych przekazów pisanych, możliwe staje się poruszenie kwestii rozmiarów parceli miejskiej, jej rozplanowania i rodzaju zabudowy, lokalizacji urządzeń gospodarczych oraz funkcji poszczególnych części działki. W efekcie celem rozważań jest wskazanie jak kształtowała się miejska przestrzeń prywatna, czy i jakim podlegała przemianom oraz określenie na ile sposób jej organizacji można traktować jako źródło do poznania przemian kulturowych w małym mieście w późnym średniowieczu. Poza zakresem zainteresowania znalazły się zatem zagadnienia związane z rozplanowaniem i rozmierzeniem Pucka. Po pierwsze, dlatego, że są one niezawodnie bardziej powiązane z problematyką urbanistyczną niż będącymi w dyspozycji Autora wynikami badań archeologicznych. Kwestie te stanowią też bez wątpienia odrębny problem, znajdujący się w pewnej mierze poza interpretacją danych uzyskanych metodą wykopaliskową. Po drugie w niewielkim stopniu można poszerzyć obecny stan wiedzy ponad dotychczasowy dorobek badań nad rozplanowaniem interesującego mnie ośrodka (Ślaski 1916, s. 2-5, 117-125; Bobiński

\footnotetext{
${ }^{1}$ Artykuł powstał w ramach realizacji projektu sfinansowanego ze środków Narodowego Centrum Nauki, przyznanych na podstawie decyzji numer DEC-2013/09/D/HS3/04468.

2 Autor przeprowadził kwerendę w archiwach Wojewódzkich Urzędów Ochrony Zabytków w Gdańsku, Słupsku i Bydgoszczy.
} 
1952, s. 132-134; Zagrodzki, 1962, s. 1-101; Dmochowska 1970; Domańska 1976; Bruski 1998, s. 73-77; Schultz 2011, s. 111-116).

Bazę źródłowa do nakreślonej wyżej tematyki stanowiły wyniki badań archeologicznych niespełna dwudziestu parcel mieszczańskich na terenie miasta lokacyjnego w Pucku (ryc. 1) (Blusiewicz, Kruppé, Milewska, Starski 2014). Na większości z nich pracami objęto jednak tylko zaplecza lub zaplecze i część środkową, co wynikało z zachowanej nowożytnej, podpiwniczonej zabudowy frontowej. Tylko w odniesieniu do dwóch parcel uzyskano dane dotyczące lokalizacji późnośredniowiecznych budynków mieszkalnych. Poza tym dostępność terenu tylko w połowie przypadków pozwoliła odsłonić większą przestrzeń działek (ryc. 1)3. W związku z powyższym jedynie w tych sytuacjach możliwe było podjęcie próby rekonstrukcji organizacji siedliska miejskiego. W rezultacie wskazanych wyżej mankamentów bazy źródłowej zagospodarowanie działek należy rozpatrywać jako wynik dotychczasowych spostrzeżeń.

Podstawą rozważań nad zagospodarowaniem parceli puckiej w późnym średniowieczu są jej wymiary. Wśród wielu innych czynników były one jednymi z najistotniejszych, wpływających zasadniczo na rozplanowanie urządzeń i zabudowy prywatnej (Pudełko 1964b, s. 115). W akcie przywileju lokacyjnego miasta z 16 listopada 1348 roku określono ich wielkość $-3 \times 7$ pręta chełmińskiego ${ }^{4}$, czyli $12,96 \times 30,24 \mathrm{~m}$; powierzchnia tak uzyskanego prostokąta wynosiła około $390 \mathrm{~m}^{2}$. Informacja ta jest jednocześnie interpretowana jako zamiar wytyczenia i zasiedlenia działek; zatem dokonano tego już po nadaniu przywileju (Bruski 1998, s. 74-76). Analiza współczesnych i archiwalnych planów Pucka dostarcza jednak danych wskazujących, że obecne parcele najczęściej mają inne wymiary od określonych w dokumencie lokacyjnym (ryc. 1,2). Większość usytuowanych przy rynku oraz część wzdłuż ulic odpowiada w przybliżeniu połowie swoich pierwotnych wymiarów, a tylko pojedyncze mają szerokość zbliżoną do $13 \mathrm{~m}$. Inne szerokości frontów siedlisk niż wspomniany moduł mają także działki w ulicach odchodzących od rynku, ale zdecydowanie rzadziej stanowi ona połowę ich pierwotnej szerokości. Także w przypadku długości często odnotowano różnicę w stosunku do określonych w przywileju $30 \mathrm{~m}$. Z reguły wydłużano je od 1 do 3 m w głąb bloku zabudowy, co zaobserwowano podczas badań archeologicznych parceli przy południowej części zachodniej pierzei rynku (ryc. 3). Zauważyć można także wydłużenie działki kosztem placu rynkowego, co poświadcza nieznaczne wysunięcie frontów kamienic w rynku względem jego pierwotnego prostokątnego kształtu (ryc. 1).

\footnotetext{
${ }^{3}$ Obszar około $0,6-0,8$ ara.

41 pręt $=4,32 \mathrm{~m}$. Powyższe wymiary parcel zastosowano także w przywileju lokacyjnym Tucholi z 1346 roku (Urkunden 1911, s. 29), a moduł ten pojawia się również w planie Lęborka i Chojnic. Poza tym na Pomorzu Gdańskim wytyczano działki o wymiarach $4 \times 6$ pręta, co odnotowano w Bytowie, Czarnem, Człuchowie i Debrznie (Betlejewska 2004, s. 121).
} 


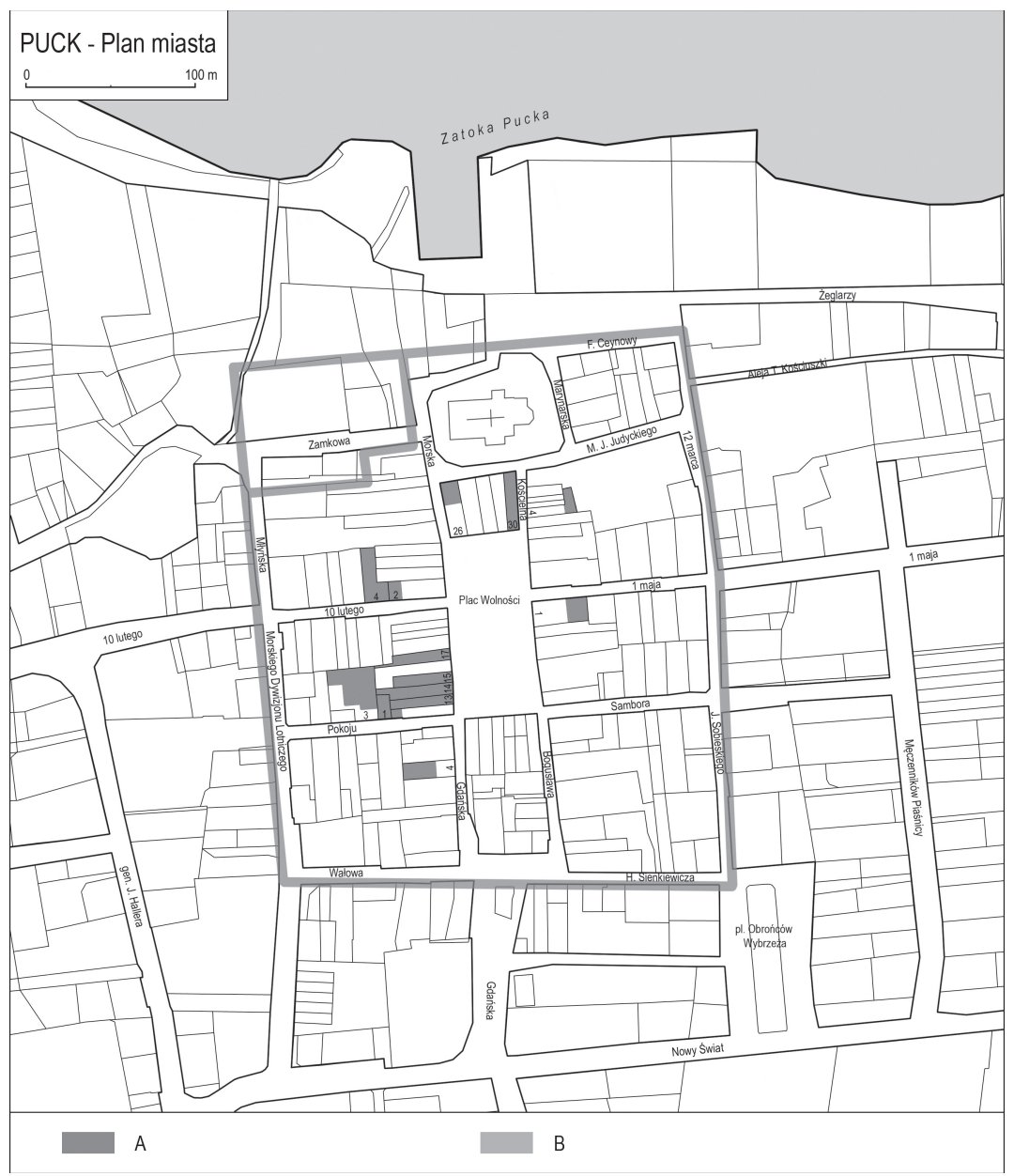

Ryc. 1. Puck. Plan miasta $\mathrm{z}$ oznaczeniem omawianych $\mathrm{w}$ tekście parcel mieszczańskich (A) oraz obrysem miasta lokacyjnego (B) (oprac. M. Starski)

Fig. 1. Puck. Plan of the town showing burghers' plots (A) discussed in the text and contour of the incorporated town (B) (prepared by M. Starski).

Pierwszym problemem badawczym jest zatem podjęcie próby ustalenia z jakimi procesami związana była zmiana wielkości działki miejskiej w lokacyjnym Pucku oraz czasu, w którym podziały te następowały. Na podstawie badań archeologicznych można sądzić, że procesy te łączyły się już z początkowym okresem istnienia miasta. Na ślady płotów, rowów drenażowych oraz relikty fundamentów wyznaczających inne granice parcel niż obecnie natrafiono bowiem w najniższych nawarstwieniach związanych z funkcjonowaniem miasta (ryc. 3, 4). W kilku przypadkach zmiany pierwotnych granic możemy rekonstruować zarówno 


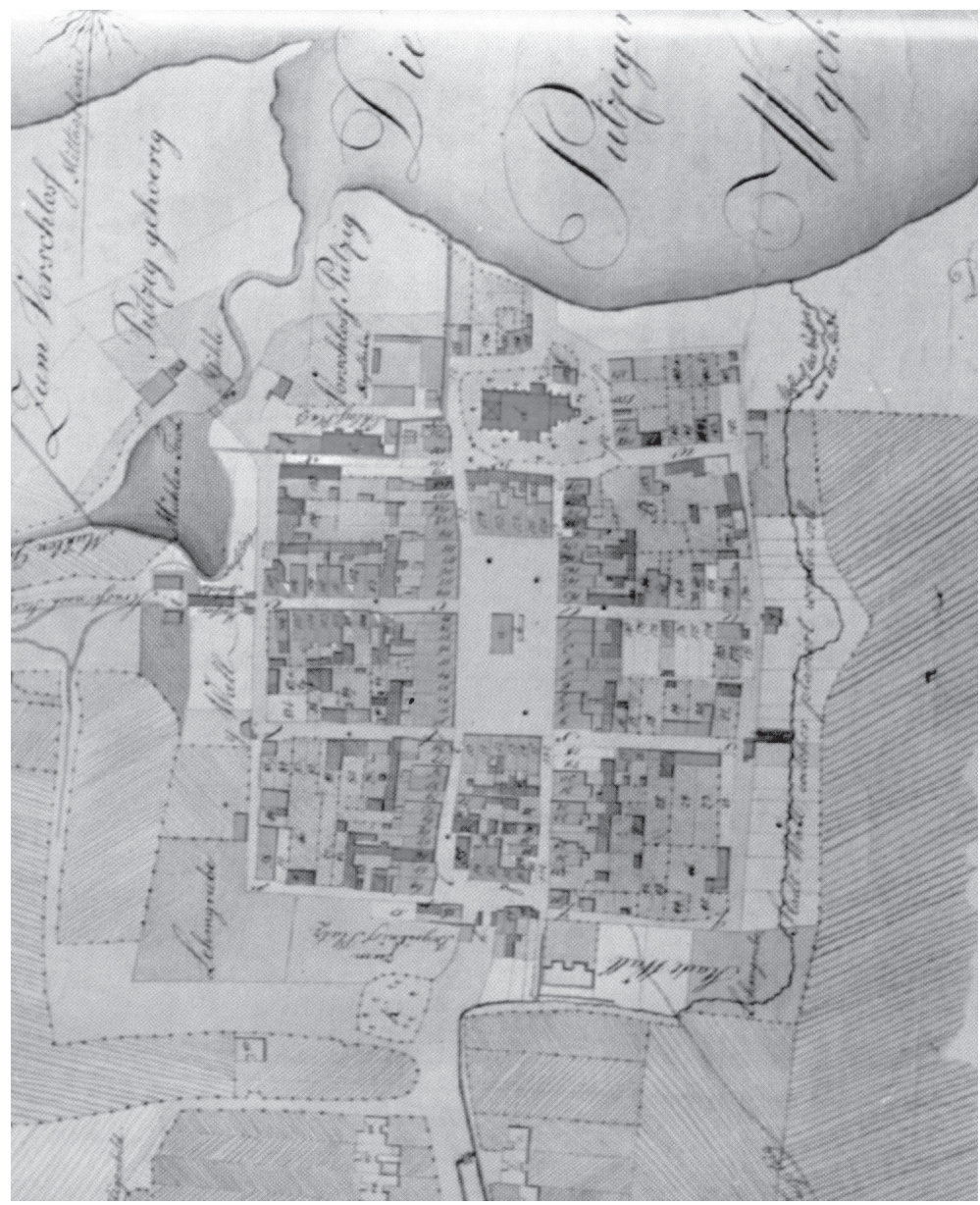

Ryc. 2. Puck. Fragment planu katastralnego miasta z 1810 roku (repr. M. Kawecki)

Fig. 2. Puck. Fragment of the cadastral plan of the town from 1810 (repr. by M. Kawecki)

dla 2. połowy XIV, jak i XV wieku; dotyczy to zarówno bocznych granic działek, jak i tylnej granicy. Można przyjąć, że już w czasie ich zasiedlania albo w starszych fazach użytkowania pierwotna siatka parcelacyjna ulegała przekształceniom na potrzeby mieszkańców Pucka. Proces ten z pewnością nie był jednoczasowy, miał miejsce już w najstarszym okresie istnienia miasta. Nie oznacza to, że później zmiany te nie następowały. Analiza rozplanowania fundamentów zabudowy nowożytnej wskazuje na dalsze przesunięcia, ale najczęściej dotyczyło to niesymetrycznego lokalizowania ściany sąsiedzkiej względem granicy działki.

${ }^{5} \mathrm{~W}$ toku analiz dendrochronologicznych ustalono, że większość badanych parcel zasiedlono już w latach 50. XIV wieku lub w 3. ćwierci tego stulecia. Na początku XV wieku miasto opłaciło czynsz za 97,5 działki ze stu określonych w przywileju (KKG 1985, s. 213). 


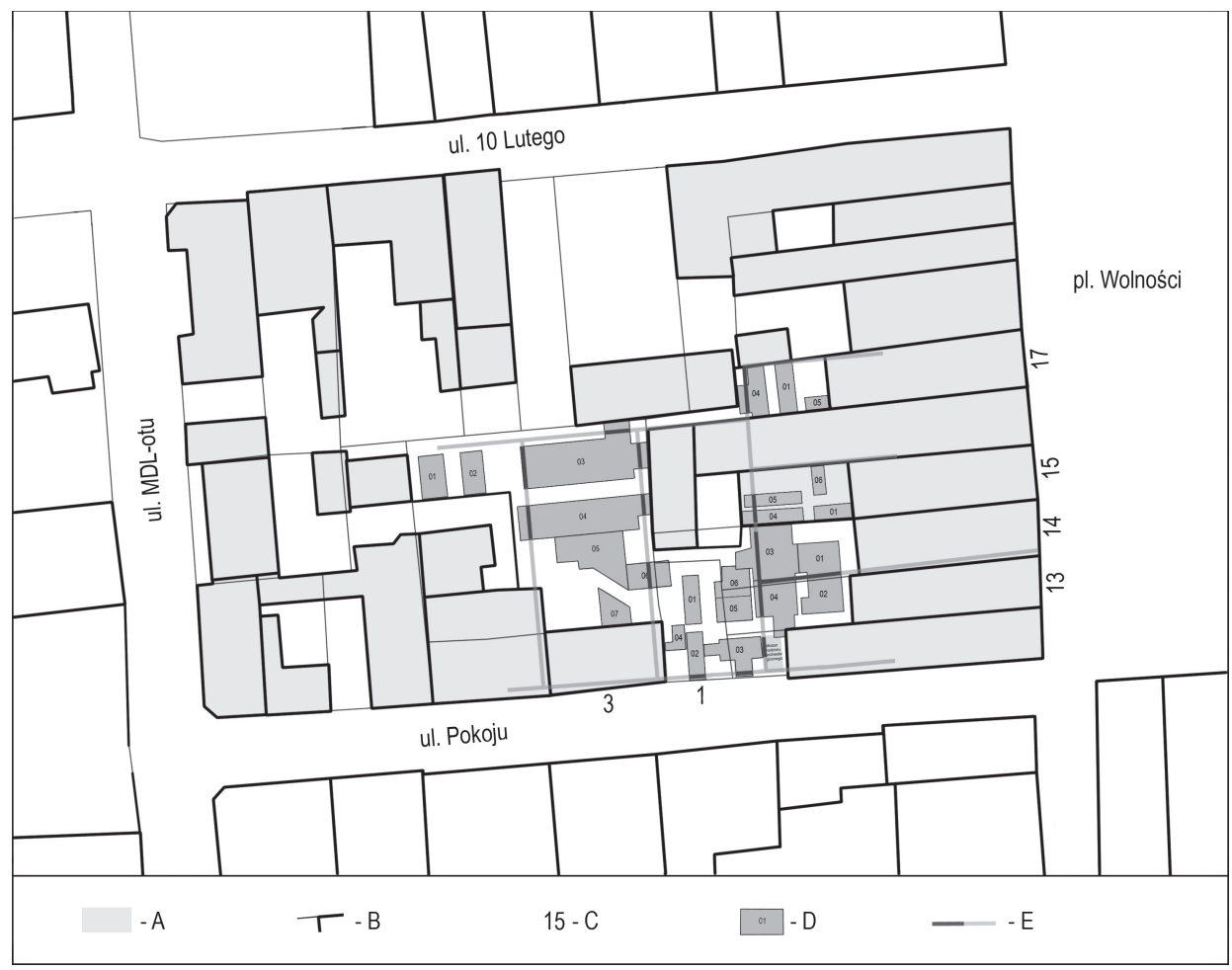

Ryc. 3. Puck. Pozostałości dawnych podziałów parcelacyjnych na tle współczesnej zabudowy i działek miejskich w południowo-zachodnim bloku zabudowy przyrynkowej. A - współczesne budynki, B - granice budynków i działek miejskich, $\mathrm{C}$ - numery badanych posesji, D - wykopy badawcze, E - odkryte i rekonstruowane płoty i rowy drenażowe zlokalizowane na granicach dawnych parcel mieszczańskich (oprac. M. Starski)

Fig. 3. Puck. Remains of the former plot divisions against the background of modern buildings and urban plots in the south-western Market Square block: A - contemporary buildings; $\mathrm{B}$ - boundaries of buildings and urban plots; $\mathrm{C}$ - numbers of studied plots; D - research trenches; E - discovered and reconstructed fences and drainage ditches located on the boundaries of former burghers' plots (prepared by M. Starski)

W świetle wyników prac terenowych można zatem uznać, że w późnośredniowiecznym Pucku często funkcjonowały mniejsze siedliska od tych określonych w przywileju lokacyjnym (półwymiarowych). Powody takiego zjawiska można wiązać zarówno z podziałem własności przy dziedziczeniu, jak i ze sprzedażą części działek, a procesy te w największym stopniu dotyczyły siedlisk przyrynkowych (ryc. 1,2). Jednak prawdopodobnie możliwość wytyczenia mniejszych parcel dopuszczono już w dokumencie lokacyjnym i podziały te funkcjonowały 


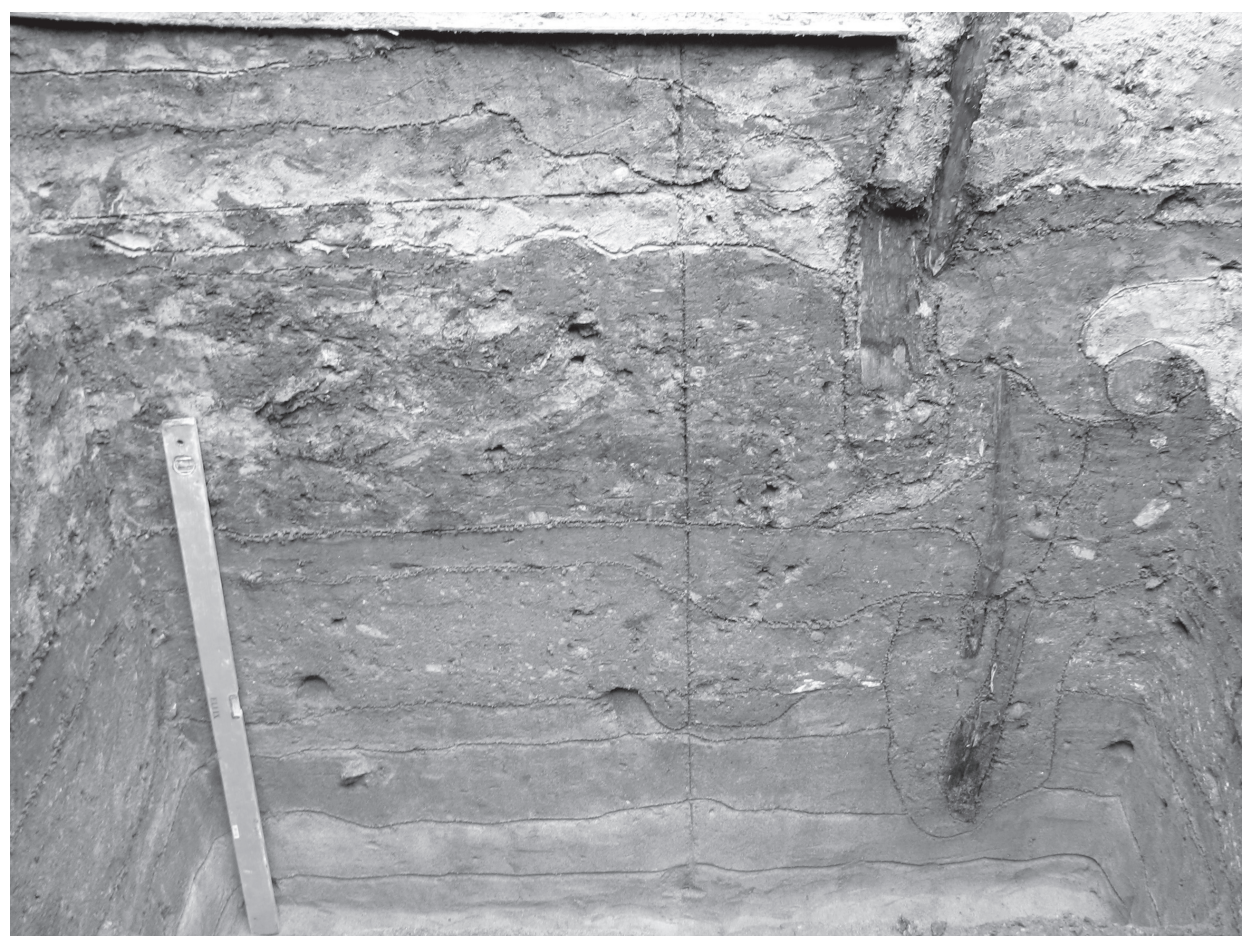

Ryc. 4. Puck, ul. 10 Lutego 4. Profil ściany północnej wykopu $06 \mathrm{z}$ widocznymi czterema poziomami płotu granicznego datowanego od 2. połowy XIV po początek XV wieku (fot. K. Blusiewicz)

Fig. 4. Puck, 10 Lutego 4 St. Section of the north face of trench 06 with four levels of the boundary fence visible dated from the second half of the $14^{\text {th }}$ to the early $15^{\text {th }}$ century (photo K. Blusiewicz)

od momentu zasiedlenia działek. W akcie tym określono bowiem ich liczbę na 100, opatrując to niejednoznacznym komentarzem dotyczącym możliwości wyznaczenia większej ich liczby ${ }^{6}$. Najprawdopodobniej nie chodziło tu o rozszerzenie zabudowy prywatnej na puste place intra muros $^{7}$, a o ewentualne podziały parcel określonych przez lokatora. Na taką interpretację wskazuje bardziej jednoznacznie sformułowany, analogiczny fragment tekstu w przywileju lokacyjnym Tucholi z 1346 roku. Dopuszczono w nim istnienie w mieście zarówno pełnych placów do zasiedlenia, jak i ich połówek ${ }^{8}$. Podobną praktykę potwierdzono zresztą w innych

\footnotetext{
${ }^{6}$, ,... ] O ile powstaną w mieście nowe siedliska albo nowe, prócz powyższego czynszu” (Ślaski 1916, s. 2).

$7 \mathrm{~W}$ momencie nadania przywileju lokacyjnego zarezerwowano plac pod budowę zamku oraz przy kościele.

${ }^{8}$, ,[...] Każdy plac w mieście ma mieć 7 prętów wzdłuż a 3 wszerz i posiadać ogród o 1 morgu, a pół placu pół morgu ogrodu" (Urkunden 1911, s. 29).
} 
miastach pomorskich, na przykład w Lęborku (Bruski 2009, s. 38-40). Próbując natomiast odnieść się do częstszego dzielenia puckich parcel przyrynkowych niż tych ulokowanych w ulicach, to widzieć tu należy najpewniej intensywniejsze w tym rejonie miasta procesy wymiany, kupna i dziedziczenia własności. W jakimś stopniu musiało to wynikać z większego zapotrzebowania, a być może i prestiżu tych działek.

Kwestia wytyczenia lub podziału parceli mieszczańskiej na mniejsze siedliska pozostawała w bezpośrednim związku z ich zagospodarowaniem, choć należy mieć na uwadze, że decydowały o tym także inne czynniki, związane choćby z wykonywanym przez mieszkańców zawodem. Mniejsze parcele wymuszały bowiem nieco inną organizację przestrzeni niż szersze, o wymiarach określonych w przywileju lokacyjnym. Charakterystykę tego zagadnienia należy zatem rozpatrywać w pewnym stopniu odrębnie dla dwóch dominujących w mieście w późnym średniowieczu wielkości działek, z jednej strony o wymiarach w przybliżeniu $13 \times 30 \mathrm{~m}$, z drugiej zaś około $6 \times 30 \mathrm{~m}$. Szczęśliwie na obu tych kategoriach parcel prowadzono badania archeologiczne umożliwiające rekonstrukcję zagospodarowania przynajmniej części ich przestrzeni. W dwóch przypadkach uzyskano dane dotyczące zabudowy frontowej, w pozostałych zaś zagospodarowania części środkowej i tylnej. Mimo stosunkowo nielicznej bazy źródłowej zanotowano zróżnicowanie sposobów zagospodarowania dawnych siedlisk, scharakteryzowanych poniżej na wybranych przykładach.

Dwie działki, których wielkość odpowiadała w przybliżeniu ich pierwotnym lokacyjnym wymiarom (tzw. pełnowymiarowe) znajdowały się przy ulicy Pokoju 1 i 3 (ryc. 1, 3). Na pierwszej pracami objęto front i część środkową (Blusiewicz 2010); natrafiono tam na pozostałości zagospodarowania terenu z 3. ćwierci XIV wieku'. Z zabudowy frontowej zachowały się relikty drewnianego podpiwniczonego budynku mieszkalnego, wzniesionego w konstrukcji szkieletowej, którego wymiary wynosiły $5 \times$ około $5 \mathrm{~m}$ (ryc. 5 ). W jego narożniku wkopano dwie postawione na sobie beczki, stanowiące najpewniej drenaż odwadniający. Dom znajdował się w południowo-zachodnim narożniku działki, a na pozostałej długości jej granicy frontowej wzniesiono jedynie drewniany płot. W głębi parceli, w odległości $10 \mathrm{~m}$ od frontu, wzniesiono w konstrukcji ramowej i międzysłupowej kolejne, podłużne zabudowanie, zorientowane poprzecznie do osi działki (ryc. 5). Najpewniej pełniło ono funkcję gospodarczą, związaną z hodowlą zwierząt. Zabudowanie miało wymiary przynajmniej $4 \times 7 \mathrm{~m}$ i dostawiono je do wschodniej granicy działki. Zapewne przejście na jej zaplecze zlokalizowano przy zachodniej granicy, czyli za frontowym zabudowaniem mieszkalnym. Niewiele wiadomo natomiast o jej tylnej, zabudowanej dziś części. Rozpoznano ją jedynie wąskimi pasami wzdłuż zachodniej i wschodniej granicy działki, jednak nie odsłonięto tam reliktów

9 Budynki wzniesiono $\mathrm{z}$ drewna, którego ścięcie datowano dendrochronologicznie od zimy 1344/1345 roku do około 1365 roku. 


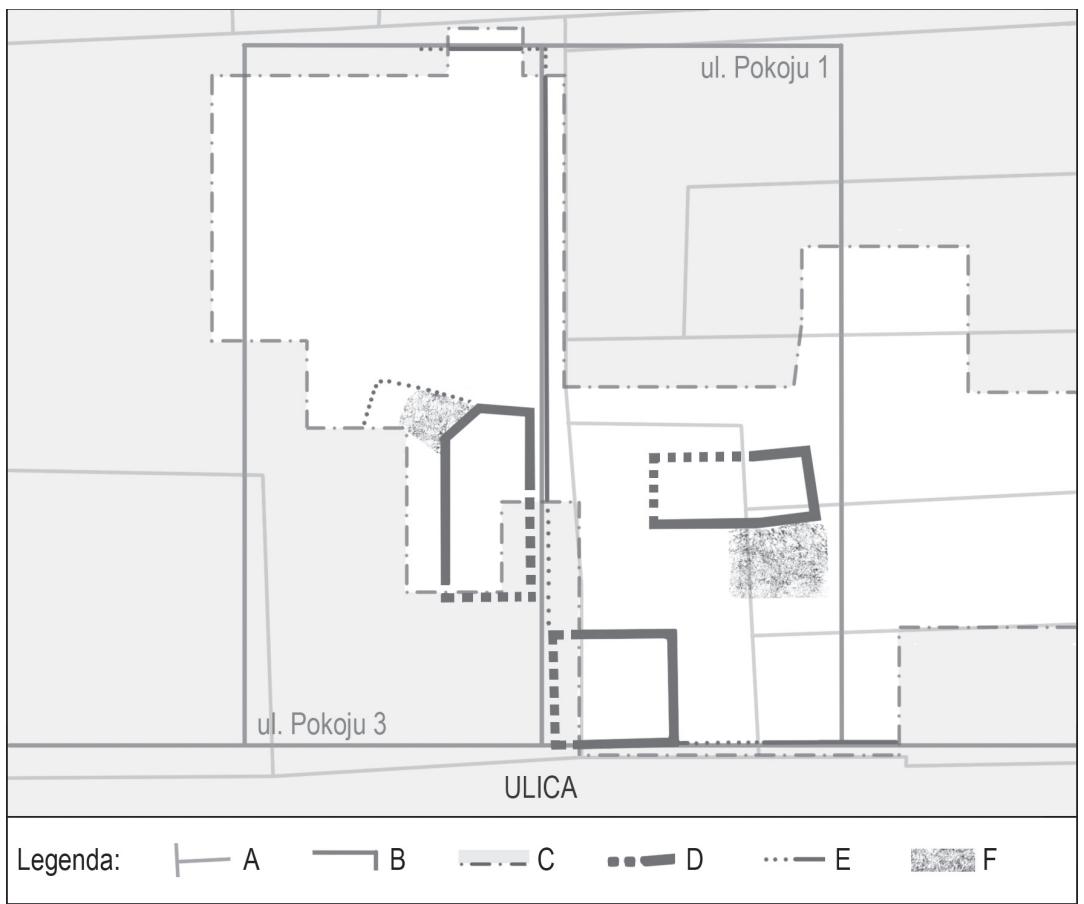

Ryc. 5. Puck, ul. Pokoju 1 i 3. Zagospodarowanie parcel miejskich w świetle wyników badań archeologicznych. A - granice współczesnych działek miejskich, B - hipotetyczne granice rekonstruowanych parcel lokacyjnych, $\mathrm{C}$ - granica obszaru rozpoznanego w toku prac wykopaliskowych, D - odkryty i rekonstruowany przebieg zabudowy, E - odkryty i rekonstruowany przebieg płotów, F - odkryte bruki (wg Blusiewicz 2010; Starski 2013)

Fig. 5. Puck, Pokoju 1 and 3 St. Organization of urban plot in the light of archaeological excavations. A - boundaries of contemporary urban plots; $\mathrm{B}$ - hypothetical boundaries of reconstructed incorporation plots; $\mathrm{C}$ - boundary of the area determined in the course of excavations; D - discovered and reconstructed course of buildings; E - discovered and reconstructed course of fences; F - discovered cobbled surfaces (after Blusiewicz 2010; Starski 2013)

konstrukcji lub zabudowy z 2. połowy XIV wieku, a jedynie znacznej miąższości nawarstwienia. Niewykluczone zatem, że zaplecze parceli pełniło funkcję ogrodu, wybiegu dla zwierząt, choć mogła się tam znajdować także latryna, bowiem nie było jej w części frontowej i środkowej parceli. Być może miejsce to zajmowały także urządzenia powiązane z produkcją rzemieślniczą. Odkryte podczas badań ruchome materiały źródłowe nie poświadczają jednak w jednoznaczny sposób zajęć mieszkańców, bowiem natrafiono na przedmioty związane z produkcją tkacką, ale także wyroby oraz półsurowce drewniane i skórzane. Opisany sposób zagospodarowania działki funkcjonował przynajmniej do końca XIV wieku. 
W 2. połowie XV wieku była ona już niezamieszkała, a jej wschodnią i północną część włączono do zaplecza parceli przyrynkowych.

$\mathrm{Na}$ drugiej z pełnowymiarowych działek, położonej na zachód od wyżej opisanej, badaniami szerokopłaszczyznowymi objęto tylną i środkową część (ryc. 3), stwierdzając zdecydowanie mniej złożony układ nawarstwień (Starski 2012). Z najstarszym okresem dziejów miasta związany był bowiem tylko jeden niewielkiej miąższości poziom warstw. Można przypuszczać, że na całej tylnej części działki (około $14 \times 13 \mathrm{~m}$ ) nie zrealizowano żadnych inwestycji budowlanych w późnym średniowieczu. Wyróżniono tu jedynie kilka jam odpadkowych i posłupowych. O użytkowaniu parceli w tym czasie świadczą natomiast relikty konstrukcji drewnianych odsłonięte w jej środkowej części (ryc. 5). Zostały one zniszczone przez współczesne instalacje techniczne i odkryte tylko częściowo, co utrudnia ich pewną identyfikację. Prawdopodobnie poświadczają one jednak istnienie budynku wzniesionego w konstrukcji słupowej bądź ryglowej, wzdłuż zachodniej granicy działki, a także płotu lub ściany z dranic dębowych, oddzielającej środkową i frontową strefę zabudowaną(?) od tylnej, pozbawionej zabudowy. Datowanie dendrochronologiczne omawianych konstrukcji wskazuje na 4. ćwierć XIV i 1. ćwierć XV wieku. Wydobyte z ich wnętrza fragmenty naczyń ceramicznych, wyrobów kowalskich i szewskich nie dały podstaw do zawężenia chronologii poza bardzo ogólnie określony XV wiek, jak też do rekonstrukcji zajęć ludności zajmującej parcelę. Niemożliwe było również ustalenie zasięgu odsłoniętych konstrukcji drewnianych, bowiem zostały zniszczone przez współczesną zabudowę mieszkalną. Ich lokalizacja wskazuje jednak na rodzaj budynku gospodarczego wzniesionego w środkowej części parceli. Za jego linią, na zapleczu działki, w późnym średniowieczu znajdował się najpewniej ogród, wybieg lub zagroda dla zwierząt. Teren ten nie był zabudowany i nie zlokalizowano tu żadnych urządzeń o funkcji sanitarnej, produkcyjnej lub budynków gospodarczych. Taki sposób organizacji terenu funkcjonował na opisywanej parceli przynajmniej do końca XV wieku.

Obraz zagospodarowania zapleczy parcel pełnowymiarowych w najstarszym okresie funkcjonowania miasta można też uzupełnić danymi z badań działek podzielonych w późniejszym czasie na mniejsze. W ich najstarszych nawarstwieniach na zapleczach także bardzo rzadkie były zabudowania gospodarcze. Jedynie na infrastrukturę dwóch składały się latryny, najpewniej też i ich zadaszenia, oraz konstrukcje związane z przetrzymywaniem zwierząt, a w jednym przypadku piecowisko związane z nieokreśloną produkcją rzemieślniczą. Wszystkie te odkrycia pochodzą z 2. połowy XIV lub początku XV wieku, sprzed podziału parceli na mniejsze siedliska.

Na tym tle inaczej prezentują się wyniki badań archeologicznych działek miejskich o szerokości odpowiadającej w przybliżeniu połowie lokacyjnej parceli puckiej. Bazowano przy tym na większej niż poprzednio liczbie niespełna 10 
dostatecznie szeroko rozpoznanych działek (ryc. 1), ale tylko w jednym przypadku uzyskano dane odnośnie zabudowy frontowej. Przede wszystkim zaplecza były zdecydowanie gęściej zagospodarowane w porównaniu z dwoma powyżej opisanymi przykładami, poza tym w ciągu półtora stulecia najstarszej historii miasta przynajmniej raz dokonano zmiany rozplanowania znajdujących się tam urządzeń i zabudowań. Zadokumentowano przy tym zarówno konstrukcje o charakterze sanitarnym, związane z produkcją rzemieślniczą, jak też zabudowę gospodarczą, a także ślady utwardzonych ciągów komunikacyjnych (ryc. 6).

$\mathrm{Na}$ relikty budynku mieszkalnego, zlokalizowanego we frontowej części działki, natrafiono na parceli przy ulicy 10 Lutego 2. Odsłonięto tam pozostałości nieznacznie wkopanej belki podwalinowej z pazą i resztkami pionowo osadzonych kołków (ryc. 7: A). Stanowiły one pozostałość zabudowania o szerokości $5 \mathrm{~m}$ i długości nie mniejszej niż 4 m, wzniesionego w konstrukcji szkieletowej. Funkcjonowało ono tylko w 2. połowie XIV wieku, a w końcowej fazie użytkowania dostawiono do niego aneks o szerokości przynajmniej $4 \mathrm{~m}$. Zachowały się jego belki podwalinowe i drewniane moszczenie podłogi. W 1. połowie XV wieku budynek rozebrano, a teren parceli włączono do działki przyrynkowej.

W pozostałych przypadkach badano tylko środkowe lub tylne części parcel. W 2. połowie XIV wieku zazwyczaj były one niezabudowane, a jedynie ogrodzone płotem. Niewykluczone, że tak jak i w przypadku parcel pełnowymiarowych znajdowały się na nich wybieg lub zagroda dla zwierząt albo przydomowy ogród. Jedynie w trzech przypadkach natrafiono na latryny. W jednym zaś, w środkowej części parceli, znajdował się też piec służący zapewne do suszenia słodu. Odsłonięto jego podłużną ceglaną podmurówkę $\mathrm{z}$ wyraźnie przepalonym pasem odpowiadającym komorze paleniskowej (ryc. 7: B). Taki obraz zaplecza przedstawia parcela przyrynkowa na Placu Wolności 13 (ryc. 6), która najprawdopodobniej już w 2. połowie XIV wieku miała wymiary około 1,5 × 7 prętów (Starski 2013). Podczas badań archeologicznych rozpoznano jedynie $12 \mathrm{~m}$ długości jej zaplecza $\left(78 \mathrm{~m}^{2}\right)$, bowiem części środkowa i frontowa zostały zabudowane podpiwniczoną kamienicą, której powstanie datuje się od schyłku czasów nowożytnych do początku XX wieku. Po osi granicy parceli zachowały się też płoty oddzielające ją od zapleczy sąsiednich siedlisk. Na podobnej wielkości parceli przy Placu Wolności 14 odnotowano natomiast funkcjonowanie zarówno wybiegu dla zwierząt, jak i zabudowy gospodarczej związanej zapewne z ich przetrzymywaniem (Starski 2013). Niewielką obórkę o wymiarach około $3 \times 4 \mathrm{~m}$ lub więcej wzniesiono prostopadle do osi działki, oddzielając obejście dla zwierząt od strefy mieszkalnej i związanej z produkcją rzemieślniczą (ryc. 6). W tym przypadku najprawdopodobniej bliżej frontu wzniesiono także latrynę, bowiem nie odnaleziono jej na zapleczu działki, a jej części środkowej, tak jak w poprzednim przypadku, nie rozpoznano.

Zagospodarowanie zapleczy parcel ulegało zmianie od końca XIV lub w ciągu XV wieku. Na niemal wszystkich stwierdzono funkcjonowanie kloaki, która 


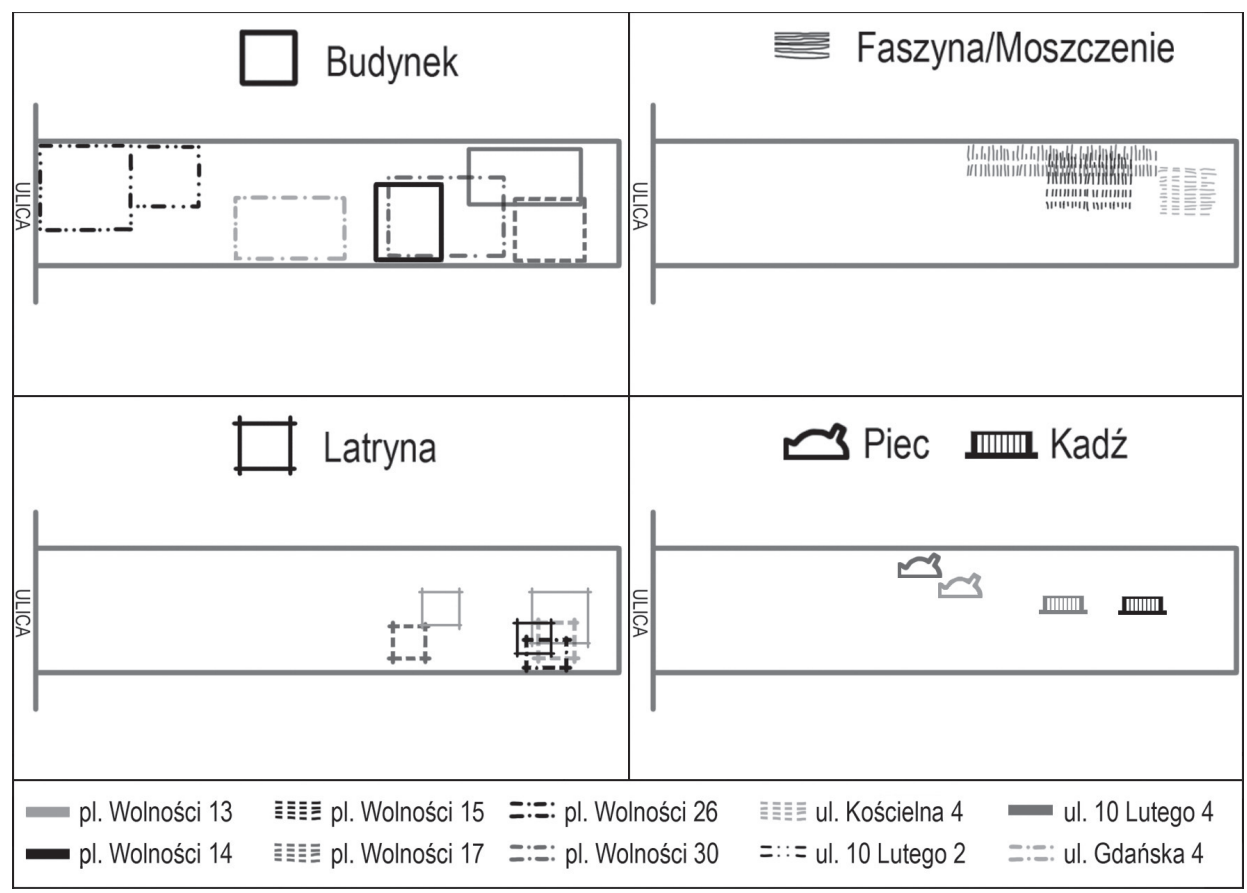

Ryc. 6. Puck. Planigrafia odkrytych konstrukcji i urządzeń z 2. połowy XIV i XV wieku na parcelach półwymiarowych (oprac. M. Starski)

Fig. 6. Puck. Plan of discovered structures and equipment from the second half of the $14^{\text {th }}$ and $15^{\text {th }}$ century on half-size plots (prepared by M. Starski).

najczęściej była zlokalizowana wzdłuż jednej z granic działki - albo na samym jej końcu (ryc. 6), albo nieco bliżej frontu. Poza nią, wzdłuż drugiej granicy bądź na całej powierzchni znajdował się utwardzony ciąg komunikacyjny w postaci faszyny lub moszczenia luźno rzuconymi deskami. Stwierdzono również zabudowę drewnianą, przy czym mogła być ona związana zarówno z zadaszeniem latryny, jak też z innym wolno stojącym zabudowaniem gospodarczym. Były to niewielkie konstrukcje drewniane, $\mathrm{z}$ reguły szkieletowe lub międzysłupowe, wzniesione zazwyczaj wzdłuż granicy działki. Badania zapleczy przyniosły również odkrycia związane bezpośrednio lub pośrednio z produkcją rzemieślniczą. Były to głównie ceglane podstawy pieców o nieokreślonej funkcji. Poza tym odsłonięto kadzie datowane na XV wiek (ryc. 7: C), wypełnione w połowie wapnem, służące zapewne do dołowania i odwłasiania skór przed ich właściwym garbowaniem (Samsonowicz 1982, s. 44-47). O produkcji szewskiej na innej parceli świadczą liczne odkrycia ścinków nieobrobionej skóry, półsurowców, wyrobów skórzanych oraz żelaznych szydeł i igły (Blusiewicz 2013). Lokalizacja urządzeń produkcyjnych była różnorodna; szczególnie widoczne jest to w przypadku ogniowych, które odnotowano zarówno na samym końcu parceli, jak i w około $2 / 3$ jej długości. 

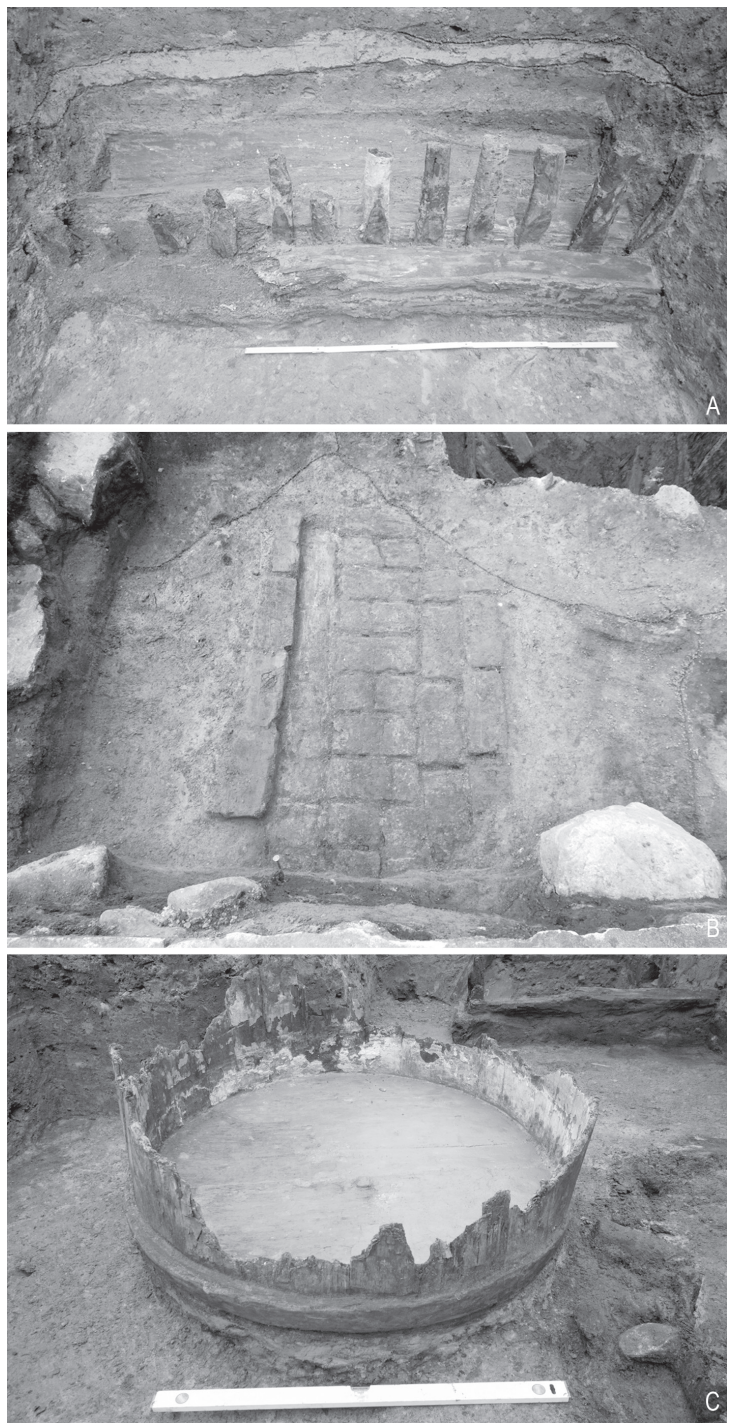

Ryc. 7. Puck. Wybrane konstrukcje odkryte na parcelach półwymiarowych. A - relikty belki podwalinowej budynku szkieletowego, ul. 10 Lutego 2 (2. połowa XIV wieku), B - pozostałości pieca do suszenia słodu, Plac Wolności 13 (2. połowa XIV wieku), C - kadź garbarska, Plac Wolności 14 (2. połowa XV wieku) (fot. M. Starski)

Fig. 7. Puck. Selected structures discovered on half-size plots. A - remains of the foundation beam of a timber-framed building, 10 Lutego 2 St. (second half of the $14^{\text {th }}$ century); B - remains of malt drying kiln, Wolności Square 13 (second half of the $14^{\text {th }}$ century); C - tannery vat, Wolności Square 14 (second half of the $15^{\text {th }}$ century) (photo M. Starski). 
Omówione wyżej przykłady pozwalają podjąć kwestię zagospodarowania parcel puckich w późnym średniowieczu. Podstawą rekonstrukcji są obserwacje z kilku badanych działek, bowiem w żadnym przypadku nie było możliwe odsłonięcie całej ich powierzchni. Pełnowymiarowe parcele mieszczańskie po zasiedleniu były zagospodarowywane stopniowo. W pierwszym etapie wznoszono w ich frontowej części budynek mieszkalny w konstrukcji szkieletowej, o wymiarach około $5 \times 5 \mathrm{~m}$. Nieco później przystępowano do budowy zabudowań gospodarczych w środkowej części parceli, tylna zaś z reguły nie była zabudowana, znajdowały się na niej urządzenia o charakterze sanitarnym lub zagrody dla zwierząt czy ogrody. Lokalizacja zaplecza gospodarczego jest w tym przypadku bardzo istotna, bowiem należy mieć na uwadze, że miasto w 2. połowie XIV wieku dopiero się organizowało i najpilniejszą potrzebą mieszkańców, poza dachem nad głową, było zapewnienie sobie żywności. Taki model zagospodarowania parcel zrealizowano najpewniej w dwóch przypadkach - przy ulicy Pokoju 1 i 3 (ryc. 8). Znamienne jest, że w XV-wiecznych nawarstwieniach na parcelach pełnowymiarowych nie odnotowano zmian $\mathrm{w}$ organizacji siedliska. Zagospodarowanie ich zaplecza w późnym średniowieczu było ekstensywne; przez cały czas znajdował się tam ogród lub obejście dla zwierząt, a zabudowa mieszkalna i gospodarcza zamykała się we frontowej części posesji.

W odniesieniu do półwymiarowych parcel przyrynkowych i w ulicach, bez względu na to, czy podział usankcjonowano przy ich wytyczeniu, czy w rezultacie późniejszych zmian własnościowych, stwierdzono pewne odrębne cechy sposobu organizacji i czasu zabudowywania ich obszaru (ryc. 9). Niezaprzeczalnie jednak pierwszym etapem zasiedlenia było wzniesienie domu mieszkalnego, którego zrekonstruowane wymiary wynosiły około $5 \times 5 \mathrm{~m}$. W związku z uzyskaniem danych jedynie odnośnie dwóch kwadratowych w planie budynków niemożliwe jest odniesienie się do poruszanej w literaturze przedmiotu kwestii lokalizowania domu mieszkalnego szczytem bądź kalenicą do ulicy (Gupieniec 1997, s. 13-16). Potwierdzenie znajduje natomiast jego lokalizacja we frontowej części działki. W jednym przypadku, dla końca XIV wieku, odnotowano też rozbudowę budynku mieszkalnego przez dostawienie do niego aneksu. Za nim znajdowała się druga linia zabudowy gospodarczej lub związanej z produkcją rzemieślniczą, którą wzniesiono nieco później od budynku mieszkalnego - w 3. lub 4. ćwierci XIV albo na początku następnego stulecia. Lokalizowano ją wzdłuż granicy działki, przy czym nie jest poświadczone jej łączenie z budynkiem frontowym. Obok zabudowania gospodarczego istniało przejście faszynowane lub moszczone drewnem. W tylnej części parceli mieściła się kloaka, sytuowana zarówno na samym jej końcu, jak i w około 2/3 długości. Budynki gospodarcze lub urządzenia produkcyjne stosunkowo rzadko budowano na samym końcu działki, z reguły w $2 / 3$ jej długości, w rezultacie mniej było wolnej, niezagospodarowanej przestrzeni. Działki półkuryjne cechowały procesy urbanizacyjne i organizacja 


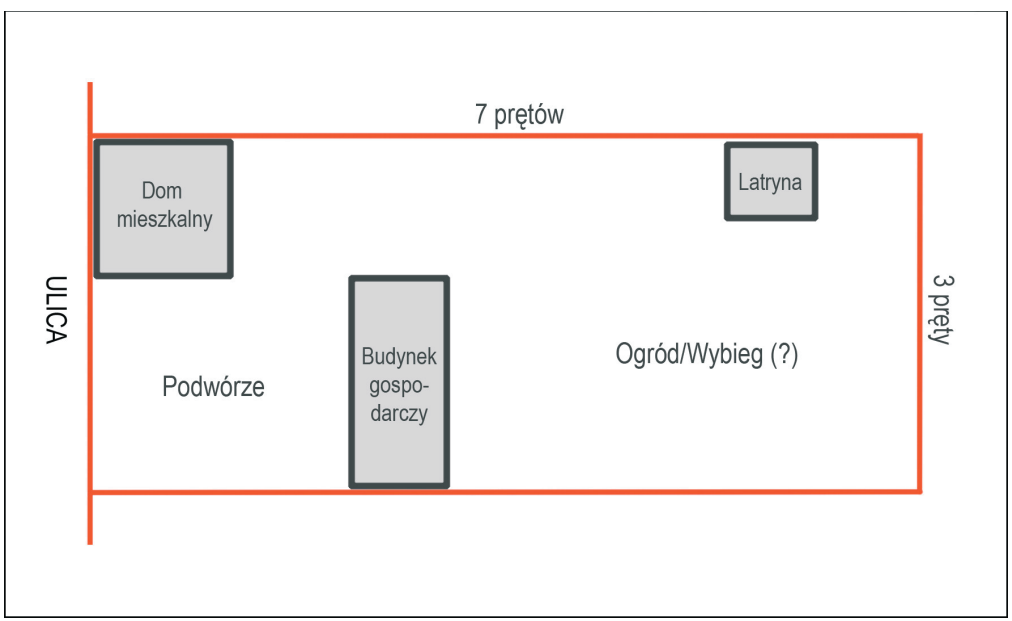

Ryc. 8. Puck. Schematyczna rekonstrukcja zagospodarowania parceli pełnowymiarowej, 2. połowa XIV wieku (oprac. M. Starski)

Fig. 8. Puck. Schematic reconstruction of the organisational layout of a full-sized plot, second half of the $14^{\text {th }}$ century (prepared by M. Starski)

siedliska widoczna także w większych ośrodkach miejskich. Ma to liczne analogie na ziemiach polskich, a także na południowym wybrzeżu Bałtyku (Gupieniec 1997, s. 15-22; Buśko 1998, s. 12).

Stwierdzono, że w zagospodarowaniu przestrzeni półtoraprętowej parceli puckiej rysuje się jedna wyraźna zmiana w ciągu badanego okresu. Na początku jej zasiedlenia zabudowa skupiona była jedynie we frontowej części, na zapleczu zaś odnotowano tylko latrynę ${ }^{10}$. Dopiero w końcu XIV i na początku XV wieku rozplanowanie przestrzenne zabudowy i urządzeń obejmowało cały obszar parceli, a na jej zapleczu, poza obiektami sanitarnymi, pojawiły się urządzenia produkcyjne lub zabudowania gospodarcze. Na podstawie dostępnej bazy źródłowej zrekonstruowano różne warianty zagospodarowania zapleczy, ale niemożliwe było wychwycenie reguł lokalizowania na nich poszczególnych konstrukcji.

W tym kontekście istotne jest odniesienie się do powodu dzielenia pełnowymiarowej parceli puckiej. Zjawisko to, jak już wspomniano, związane było między innymi z dziedziczeniem lub podziałem własności w celach handlowych. Jednocześnie były to naturalne procesy w rozwijającym się mieście (Gupieniec 1997, s. 22-24). Częstsze ich występowanie w odniesieniu do działek przyrynkowych w małym ośrodku najprawdopodobniej wynikało z kwestii waloryzacji jego przestrzeni, związanych z kształtowaniem się topografii osadniczej miasta. Parcele przy rynku musiały się cieszyć większym zainteresowaniem i stąd skupienie w tym rejonie Pucka akcji związanych z dzieleniem siedlisk. Ich podział można

${ }^{10}$ Dotyczy to potwierdzonych wykopaliskowo budynków mieszkalnych, ale niewykluczone, że za nimi znajdowały się także gospodarcze. 


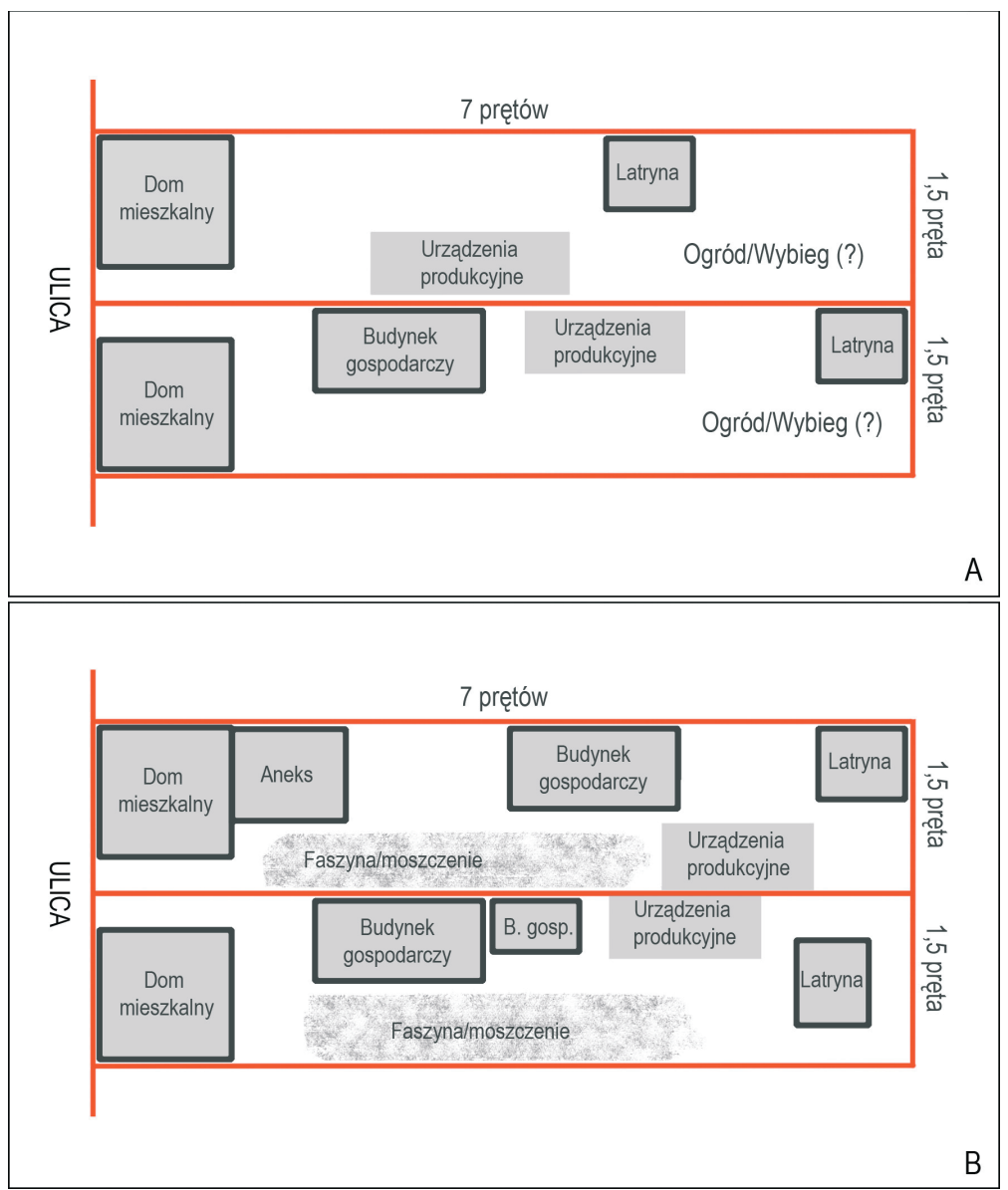

Ryc. 9. Puck. Schematyczna rekonstrukcja zagospodarowania parceli półwymiarowej. A - 2. połowa XIV wieku, B - 2. połowa XV wieku (oprac. M. Starski)

Fig. 9. Puck. Schematic reconstruction of the organisational layout of a full-sized plot. A - second half of the $14^{\text {th }}$ century; B - second half of the $15^{\text {th }}$ century (prepared by M. Starski)

by zatem tłumaczyć większym prestiżem oraz popytem i należy w nim widzieć proces kształtowania się trzonu przestrzeni miejskiej. Odbiega to nieco od sytuacji widocznej w większych ośrodkach strefy bałtyckiej, w których wielkość i podziały parceli związane były ściślej z uwarunkowaniami gospodarczymi w czasie powstawania miasta oraz przynależnością społeczną i zawodową ich właścicieli (Gupieniec 1997, s. 22-24). Właściwe określenie różnic między wielkimi a małymi miastami z pewnością wymaga jednak dalszych prac badawczych, szczególnie w przypadku tych drugich. Wobec niedostatku zachowanych źródeł pisanych niezbędne wydają się dalsze szerokopłaszczyznowe badania wykopaliskowe. 
Wpływ na zagospodarowanie parcel miejskich w Pucku miały też zajęcia jej mieszkańców, które wiązały się z lokalizacją w obrębie podwórza infrastruktury rzemieślniczej. Nie stwierdzono przy tym reguły w zakresie jej sytuowania w części środkowej parceli lub na samym zapleczu (ryc. 6). Znamienne jest, że na podwórzach parcel przyrynkowych, a więc niewątpliwie położonych w centralnej części miasta, występowały obiekty poświadczające uciążliwą dla mieszkańców działalność gospodarczą (np. garbarstwo), jak też stanowiące zagrożenie pożarowe (piecowiska związane z produkcją piwowarską i inną). Świadczy to zatem o zamieszkiwaniu parcel przyrynkowych przez rzemieślników. O działkach peryferyjnych wiadomo niewiele, ale na dwóch pełnowymiarowych, zlokalizowanych przy ulicy Pokoju 1 i 3, nie jest poświadczona produkcja rzemieślnicza. Ich podwórza były niezabudowane, a wykorzystywano je najpewniej do hodowli zwierząt. Możliwe, że zamieszkująca je ludność trudniła się zajęciami rolniczymi bądź, co możliwe w przypadku Pucka, rybołówstwem. Skądinąd odsetek mieszkańców małych miast, którym przypisywano zajęcia rolnicze rekonstruowany jest przez historyków na poziomie od około 25 do 50\% (Bogucka, Samsonowicz 1986, s. 161). Nie oznacza to reguły, że wszystkie pełnowymiarowe parcele w ulicach należałoby wiązać z ludnością rolniczą mieszkającą w obrębie miasta, ale poświadcza jednostkowe przypadki takiej ewentualności. Niewykluczone, że opisywany tu model użytkowania podwórza może wynikać także z rejonu miasta, w którym prowadzono badania. Parcele przy ulicy Pokoju znajdowały się poza rynkiem i głównymi ulicami, prowadzącymi do bram miejskich. Przypuszczalnie zatem mogła to być nieco uboższa część miasta, choć rozwarstwienie majątkowe mieszczan małych miast nie było zapewne nigdy tak znaczne jak w wielkich ośrodkach miejskich.

W zakresie zagospodarowania parcel miejskich w późnośredniowiecznym Pucku komentarza wymaga zagadnienie zaopatrzenia ich mieszkańców w wodę. Na żadnej z badanych działek nie znaleziono studni, co nawet na obecnej, ograniczonej podstawie źródłowej, pozwala twierdzić, że nie budowano ich na działkach prywatnych, a znajdowały się w przestrzeni publicznej miasta. Nieco światła na tę kwestię rzucają nowożytne i współczesne źródła kartograficzne. Na najstarszym, XVII-wiecznym planie Pucka schematycznie zaznaczono cztery studnie w rynku, natomiast plan katastralny z 1810 roku (ryc. 2) zawiera dane o ośmiu ujęciach wody, zlokalizowanych w rynku i w osi ulic. Najpewniej podobna sytuacja mogła istnieć w początkowym okresie istnienia miasta.

Badania archeologiczne parcel mieszczańskich w Pucku dostarczyły ważnych źródeł do poznania przemian kulturowych w małym mieście - kształtowania się jego przestrzeni i zajęć ludności. Potwierdziły w przybliżeniu model zagospodarowania działki znany z literatury przedmiotu jako podział na strefę mieszkalną, gospodarczą i sanitarną (Buśko 1998, s. 12). Wzbogaciły one dotychczasowy stan wiedzy także w odniesieniu do parcel, których zaplecza były wykorzystywane jedynie ekstensywnie, jako zagrody lub ogrody. Ten pierwszy model odnosi się do 
działek przyrynkowych, rzadziej zaś znajdujących się w ulicach i jest związany z produkcją rzemieślniczą ich mieszkańców. Drugi przypadek dotyczy parcel w ulicach, na których nie poświadczono produkcji rzemieślniczej, a raczej zajęcia ludności związane z rolnictwem lub hodowlą. Wniosek ten z pewnością wymaga weryfikacji w toku dalszych badań zarówno w Pucku, jak i w innych małych miastach, nie tylko pomorskich.

Na podstawie zaprezentowanego materiału źródłowego można stwierdzić, że funkcje i zagospodarowanie parcel miejskich w Pucku, w kontekście ich znaczenia dla poznania przemian kulturowych małego miasta, należy przede wszystkim interpretować jako jeden z wyznaczników procesów urbanizacyjnych. Rezultaty badań archeologicznych dostarczają bowiem danych na temat tworzenia się lokalnego ośrodka usługowo-rzemieślniczego i spełniania przez niego funkcji miejskich. Dotyczy to ściśle organizacji przestrzeni siedlisk, które jak widać na przykładzie Pucka zagospodarowywano zasadniczo podobnie do większych ośrodków pomorskich i strefy bałtyckiej (Gupieniec 1997, s. 15-22). Pokazuje to zarówno występowanie tych samych mechanizmów w różnych miastach, jak i podobny wzorzec przemian kulturowych społeczności mieszczańskiej. Mimo generalnie wyraźnych podobieństw wprowadzano je jednak na gruncie lokalnym, uwzględniając tym samym miejscowe uwarunkowania wynikające z wielkości miasta i zajęć jego mieszkańców.

\section{Literatura}

Archeologia historyczna

2000 Sesja VI. Archeologia historyczna, [w:] Archeologia i prahistoria Polska w ostatnim pótwieczu, red. M. Kobusiewicz, S. Kurnatowski, Poznań, s. $469-510$.

Berdecka A.

1982 Lokacje i zagospodarowanie miast królewskich w Małopolsce za Kazimierza Wielkiego (1333-1370), Studia i materiały z historii kultury materialnej, t. 45, red. Z. Kamieńska, Wrocław.

Betlejewska C.

2004 Rozmierzenie miast lokowanych przez zakon krzyżacki w XIV wieku, [w:] Archaeologia et historia urbana, red. R. Czaja i in., Elbląg, s. 117-124.

Blusiewicz K.

2010 Badania archeologiczne na działce 54 ul. Pokoju 1 w Pucku, [w:] Średniowieczne miasto lokacyjne w Pucku w świetle badań archeologiczno-architektonicznych projekt MNiSW N109 035 31/2586, maszynopis w archiwum Zakładu Archeologii Późnego Średniowiecza i Czasów Nowożytnych Instytutu Archeologii Uniwersytetu Warszawskiego, Warszawa. 
2013 Późnośredniowieczne obuwie z badań dziatki miejskiej w Pucku, [w:] XVII Sesja Pomorzoznawcza, t. 2: Od późnego średniowiecza do czasów nowożytnych, red. H. Paner, M. Fudziński, Gdańsk, s. 405-413.

Blusiewicz K., Kruppé J., Milewska M., Starski M.

2014 Dwadzieścia lat archeologii w mieście i na zamku puckim, [w:] Z dziejów badań archeologicznych na Pomorzu Wschodnim, red. M. Fudziński, H. Paner, Gdańsk, s. 187-200.

Bobiński S.

1952 Gdańsk wczesnodziejowy na podstawie analizy planu, Gdańsk.

Bogucka M., Samsonowicz H.

1986 Dzieje miast i mieszczaństwa w Polsce przedrozbiorowej, Wrocław.

Bruski K.

1998 Puck w czasach krzyżackich, [w:] Historia Pucka, red. A. Groth, Gdańsk, s. 68-90.

2009 Lębork w czasach średniowiecza, [w:] Dzieje Lęborka, red. J. Borzyszkowski, Lębork-Gdańsk, s. 19-98.

Buśko C.

1998 Z badań nad wewnętrznym rozplanowaniem działki mieszczańskiej na Ślasku, [w:] Miasto, red. K. Wachowski, Kultura średniowiecznego Śląska i Czech 1, Wrocław, s. 91-98.

1998 Ślask w XII i XIII wieku. Zderzenie kultur, [w:] „Rewolucja XIII wieku”, red. K. Wachowski, Kultura średniowiecznego Śląska i Czech 3, Wrocław, s. $155-159$.

Dmochowska I.

1970 Puck (studium historyczno-urbanistyczne), maszynopis w archiwum Wojewódzkiego Urzędu Ochrony Zabytków w Gdańsku, Gdańsk.

Domańska H.

1976 Puck, woj. gdańskie. Studium historyczno-urbanistyczne, maszynopis w archiwum Wojewódzkiego Urzędu Ochrony Zabytków w Gdańsku, Gdańsk.

Dzieduszycki W.

1998 Wiek XIII. Przemiany - ich specyfika i znaczenie, [w:] ,Rewolucja XIII wieku”, red. K. Wachowski, Kultura średniowiecznego Śląska i Czech 3, Wrocław, s. $17-22$.

Gupieniec R.

$1997 Z$ Z dziejów miast średniowiecznych. Próba odtworzenia stanu zabudowy dziatek budowlanych w miastach wczesno- i późnośredniowiecznych $w$ basenie Morza Baltyckiego, Mazowieckie Studia Humanistyczne, nr 2, s. 5-36.

Historia

1978 Historia kultury materialnej w zarysie, t. 2, red. A. Rutkowska-Płachcińska, Wrocław.

Ihnatowicz I., Mączak A., Zientara B.

1979 Spoleczeństwo polskie od X do XX wieku, Warszawa. 
Kierzkowska-Kalinowska E.

1975 W kwestii badań nad rozplanowaniem miasta średniowiecznego, Kwartalnik Historii Kultury Materialnej, R. 23, nr 1, s. 199-222.

KKG

1985 Księga Komturstwa Gdańskiego, wyd. K. Ciesielska, I. Janosz-Biskupowa, Warszawa-Poznań-Torun.

Krasnowolski B.

2004 Lokacyjne układy urbanistyczne na obszarze Ziemi Krakowskiej w XIII i XIV wieku, cz. 1: Miasta Ziemi Krakowskiej chronologia procesów osadniczych i typologia układów urbanistycznych, cz. 2: Katalog układów urbanistycznych, Kraków.

Kruppé J.

1981 Garncarstwo późnośredniowieczne w Polsce, Wrocław.

Krzywdziński R.

2009 Stan badań nad budownictwem drewnianym Głównego Miasta Gdańska w XIV wieku, [w:] Stan badań archeologicznych miast $w$ Polsce, red. H. Paner, M. Fudziński, Z. Borcowski, Gdańsk, s. 215-244.

Lalik T.

1963 Na marginesie powstania planu miasta średniowiecznego (na marginesie pracy T. Zagrodzkiego), Kwartalnik Historii Kultury Materialnej, R. 11, nr 2, s. 415-419.

1975 Funkcje miast i miasteczek w Polsce późniejszego średniowiecza, Kwartalnik Historii Kultury Materialnej, R. 23, nr 4, s. 551-565.

1976 Geneza sieci miasteczek w Polsce średniowiecznej, [w:] Miasta doby feudalnej w Europie środkowo-wschodniej, red. A. Gieysztor, T. Rosłanowski, Warszawa-Poznań-Toruń, s. 113-136.

Małowist M.

1973 Wschód a Zachód Europy w XIII-XVI wieku: konfrontacja struktur społeczno-gospodarczych, Warszawa.

Młynarska-Kaletynowa M.

1997 Opolskich badaniach nad miastem średniowiecznym, Archaeologia Historica Polona, t. 5, s. 13-22.

2006 O procesach lokacyjnych miast w Europie Środkowo-Wschodniej, [w:] Procesy lokacyjne miast w Europie Środkowo-Wschodniej. Materiaty z konferencji międzynarodowej w Ladku Zdroju 28-29 października 2002 roku, red. C. Buśko, M. Goliński, B. Krukiewicz, Wrocław, s. 9-17.

Münch H.

1946 Geneza rozplanowania miast wielkopolskich XIII i XIV wieku, Kraków.

Polak Z.

2007 Badania archeologiczne prowadzone w latach 2002-2004 na stanowisku „Hotel Rezydent” w Gdańsku, [w:] XV Sesja Pomorzoznawcza, red. G. Nawrolska, Elbląg, s. 359-368. 
2009 Uwagi archeologa do historii średniowiecznej kamienicy gdańskiej, [w:] Stan badań archeologicznych miast w Polsce, red. H. Paner, M. Fudziński, Z. Borcowski, Gdańsk, s. 245-256.

Pudełko J.

1964a Próba pomiarowej metody badania planów niektórych miast średniowiecznych w oparciu o zagadnienie dziatki, Kwartalnik Architektury i Urbanistyki, t. 9, z. 1, s. 13-27.

1964b Działka lokacyjna w strukturze przestrzennej średniowiecznych miast ślaskich XIII wieku, Kwartalnik Architektury i Urbanistyki, t. 9, z. 2, 115-136.

Rębkowski M.

2001 Pierwsze lokacje miast $w$ księstwie zachodniopomorskim. Przemiany przestrzenne i kulturowe, Kołobrzeg.

Samsonowicz A.

1982 Wytwórczość skórzana w Polsce wczesnofeudalnej, Studia i materiały z historii kultury materialnej, t. 44, red. Z. Kamieńska, Wrocław.

Schultz F.

2011 Dzieje powiatu wejherowskiego i puckiego, tłum. W. Sawicki, W. Szreniawski, red. R. Biskup, Gdańsk-Puck-Wejherowo.

Starski M.

2012 Sprawozdanie z badań archeologicznych przeprowadzonych w latach 2011-2012 roku przy ul. Pokoju w Pucku (działka miejska 55), maszynopis w archiwum Zakładu Archeologii Średniowiecza i Czasów Nowożytnych Instytutu Archeologii Uniwersytetu Warszawskiego, Warszawa.

2013 Sprawozdanie z badań archeologicznych przeprowadzonych w 2013 roku przy pl. Wolności 13 i 14 w Pucku (działka miejska 52 i 53), maszynopis w archiwum Zakładu Archeologii Średniowiecza i Czasów Nowożytnych Instytutu Archeologii Uniwersytetu Warszawskiego, Warszawa.

Ślaski B.

1916 Materjały i przyczynki do dziejów nadmorskiego miasta Pucka oraz dawnej ziemi Puckiej, Warszawa.

\section{Urkunden}

1911 Urkunden der Komturei Tuchel. Handfesten und Zinsbuch, oprac. P. Panske, Gdańsk.

Wędzki A.

1974 Początki reformy miejskiej w środkowej Europie do połowy XIII wieku (Słowiańszczyzna Zachodnia), Warszawa-Poznań.

Wyrobisz A.

1968 Badania nad historia małych miast w Polsce, Przegląd Historyczny, t. 49, z. 1, s. 124-138.

2010 Układ przestrzenny miasta jako źródło historyczne, [w:] Świat średniowiecza. Studia ofiarowane Profesorowi Henrykowi Samsonowiczowi, red. A. Bartoszewicz i in., Warszawa, s.163-172. 
Zagrodzki T.

1962 Regularny plan miasta średniowiecznego a limitacja miernicza, Studia Wczesnośredniowieczne, t. 5, z. 1, Wrocław.

Zarębska T.

1995 Badania historyczno-urbanistyczne metoda analiz przestrzennych, Kwartalnik Historii Kultury Materialnej, R. 53, nr 1, s. 15-32.

Zientara B.

1976 Przemiany społeczno-gospodarcze i przestrzenne miast $w$ dobie lokacji, [w:] Miasta doby feudalnej w Europie środkowo-wschodniej, red. A. Gieysztor, Żaryn S. T. Rosłanowski, Warszawa-Poznań-Toruń, s. 67-97.

1972 Trzynaście kamienic staromiejskich. Strona Dekerta, Warszawa.

ORGANIZATION OF THE BURGHERS' PLOTS IN PUCK AS EVIDENCE OF CULTURAL CHANGES IN A SMALL INCORPORATED TOWN IN THE LATE MIDDLE AGES

Summary

This article discusses the development of the middle-class area in Puck. It is based on the archaeological excavations of about twenty plots that were an attempt to reconstruct the layout and the type of buildings as well as the location of non-residential and sanitary facilities. The basis of considerations were the plot's dimensions recorded in the charter as $3 \times 7$ Chełmno rods, half-size plots were also in use in the oldest period of the town. The aforementioned measurements determined the layout of installations and private buildings. Based on analysis of source materials, it was found that the residential building was always located at the front of the plot. The back of the plot was gradually occupied by non-residential facilities and buildings. Its organization was linked with craft activity as run by residents of a given property. In terms of the buildings' layout many parallels in relation to other urban centres on the southern coast of the Baltic Sea were found. 